\title{
Determination of Optimum Calcium and Phosphorous Ratio for the Production of African Catfish Clarias gariepinus (Burchell, 1822)
}

\author{
*NWANNA, LC; ONI, OV \\ Department of Fisheries and Aquaculture Technology, Federal University of Technology, Akure, Nigeria \\ *Corresponding author Email: drlel@yahoo.com
}

\begin{abstract}
Optimum calcium-phosphorus (Ca/P) ratio for the growth of African catfish was investigated over a 70-day period with a basal diet formulated and supplemented with $\mathrm{Ca} / \mathrm{P}$ ratios of $(0: 0,1: 0.5,1: 1,2: 1.5,3: 1$ and 3.5: 1.5) respectively. The results showed that the mean weight gain and specific growth rate increased from the fish fed the control diet up to the fish fed diet with $\mathrm{Ca} / \mathrm{P}$ ratio of $2: 1.5$, and then declined consistently to the fish fed diet with $\mathrm{Ca} / \mathrm{P}$ ratio of 3.5:1.5. Addition of $\mathrm{Ca}$ and $\mathrm{P}$ in the diets significantly increased the carcass ash, while feeding the fish with the control diet supposed to be imbalance in $\mathrm{Ca} / \mathrm{P}$ ratio elevated the carcass fat and moisture. The increase in carcass ash consequently resulted in increase $(\mathrm{P}<0.05)$ in carcass minerals $(\mathrm{Ca}, \mathrm{Mg}, \mathrm{P}, \mathrm{Zn}$ and $\mathrm{Fe})$ in relation to fish fed the control diet. In conclusion, the study suggests $\mathrm{Ca} / \mathrm{P}$ ratio of $2: 1.5(1.33: 1)$ as the optimum for the production of African catfish.
\end{abstract}

\section{DOI: https://dx.doi.org/10.4314/jasem.v22i5.12}

Copyright: Copyright (C) 2018 Nwanna and Oni. This is an open access article distributed under the Creative Commons Attribution License (CCL), which permits unrestricted use, distribution, and reproduction in any medium, provided the original work is properly cited.

Dates: Received: 05 March 2018; Revised: 16 April: 2018; Accepted: 22 April 2018

Keywords: African catfish, $\mathrm{Ca} / \mathrm{P}$ ratio, growth performance, nutrient digestibility

Calcium and phosphorus are vital minerals for fish growth and maintenance of physiological functions. They make up to $70 \%$ of the total mineral elements in the body and are essential for the formation of bone, energy transfer through ATP and an essential component of buffer systems in the blood (Nwanna et al. 2010). Under practical farming conditions, mineral deficiency signs often arise from a dietary imbalance of calcium owing to the antagonistic effect of excess dietary calcium on the absorption of phosphorus (Nakamura, 1982).

Therefore, the calcium-phosphorus ratio content in the diet of a particular fish must be the quantity that will neither compromise the fish growth nor cause environmental pollution which can lead to off flavour. Although, the major source of $\mathrm{Ca}$ and $\mathrm{P}$ in aquaculture is feeds but this has to be regulated to the limit required by the fish as excess will be excreted by the fish leading to economic losses and environmental pollution.

Therefore it is critical to know precisely the dietary requirement of $\mathrm{Ca}$ and $\mathrm{P}$ in order to minimize their excess in diet without risking $\mathrm{Ca}$ and $\mathrm{P}$ deficiency in cultured fish. Hence, this study evaluated the effect of different levels of dietary calcium and phosphorus on the growth and mineral concentration in Clarias gariepinus with a view to determining the optimum $\mathrm{Ca} / \mathrm{P}$ requirement for the growth of the fish.

*Corresponding author Email: drlel@yahoo.com

\section{MATERIALS AND METHODS}

Preparation of experimental diets: Six $30 \%$ crude protein diets containing fishmeal, soyabean meal, groundnut cake meal, yellow maize, groundnut oil, vitamin/mineral premix, methionine and starch were formulated and supplemented with calcium (calcium carbonate) and phosphorus (phosphorus monophosphate) ratios of $0: 0 ; 1: 0.5 ; 1: 1 ; 2: 1.5 ; 3: 1$; and 3.5:1.5 making diets $1-6$ respectively.

Dry dietary ingredients were thoroughly mixed with hot water to form dough. The dough was then pelleted using Hobart A - 200 pelleting machine with a $2.0 \mathrm{~mm}$ die. After pelleting, the diets were sun dried $\left(27^{\circ} \mathrm{C}\right)$ for 72 hours and later broken mechanically into small sizes and packed in labelled dry, air tight small containers prior to use. Proximate analyses of the sample diets were done according to the methods of A.O.A.C (1990). The gross and proximate compositions of the diets are presented in Table 1.

Feeding trials: A total of three hundred and six (306) Clarias gariepinus post fingerlings were purchased from a reputable fish farm in Akure. The fish were acclimatized in eighteen (18) 30 -litre capacity aquarium glass tanks for 1 week. At the start of the experiment, the fish were weighed individually and grouped into 15 fish per tank according to the six treatments with three replicates per treatment. Feeding was done to apparent satiation twice daily between $0900-1100$ and $1600-1700$ hrs for 70 days. Water 
quality parameters of the experiment such as temperature, $\mathrm{pH}$ and dissolved oxygen were measured using standard method. Weight of the fish was measured bi-weekly and used to calculate the weight gain, specific growth rate (SGR) and feed conversion ratio according to Nwanna et al. (2014).

Measurements and analyses: Triplicate samples of the diets were analyzed for proximate composition according to the methods of the AOAC (1990). At the end of the experimental period, the fish were starved for $24 \mathrm{~h}$, oven dried at $45^{\circ} \mathrm{C}$ and analyzed for proximate composition following the methods of AOAC (1990).

Minerals and haematological analyses: For mineral analyses, three replicates of the blended fish carcass (whole body) were analyzed for minerals according to the methods of the AOAC (1990). While (Ca, Mg, Fe, $\mathrm{Zn}, \mathrm{Mn}$ ) were measured using atomic absorption spectrophotometer (AAS), the phosphorus (P) contents were determined using the vanadomolybophosphoric acid colorimetric method. For haematological analysis, another set of three fish were removed from each tank for blood analysis. Blood from the samples were pooled and analyzed following the method described by Svobodova et al. (2006).

Statistical analysis: Data from the experiment were subjected to one-way analysis of variance (ANOVA), using the SPSS (Statistical package of social sciences) version 16.0. Duncan's multiple range test was used to compare the differences among the individual means at $\mathrm{P}=0.05$

\section{RESULTS AND DISCUSSION}

When fish are fed diets with excess calcium over phosphorus, the phosphorus is not absorbed by the intestines because it combines with calcium to form calcium phosphate that is not biologically available (Nwanna et al. 2010). This leads to adverse effect on the growth and survival of fish (Ye et al. 2006; Nwanna et al. 2010; Hassan et al. 2013). Besides, imbalance in $\mathrm{Ca} / \mathrm{P}$ ratio has several aberrations in bone mineral homeostasis and body meatabolism (Kumar et al. 2011).

Therefore this study investigated the effects of different combinations of $\mathrm{Ca}$ and $\mathrm{P}$ in diets on the growth, nutrient utilization, mineral and haematological profile of African catfish (Clarias gariepinus) with a view to determining the optimum dietary $\mathrm{Ca} / \mathrm{P}$ ratio for the fish. The proximate composition of the experimental diets (Table 1) are closely related, therefore any changes in the growth performance and nutrient utilization by the fish could be attributed to the effects of supplemental $\mathrm{Ca}$ and $\mathrm{P}$ in the diets. The results of growth and nutrients utilization by the fish (Table 2) indicated that addition of $\mathrm{Ca}$ and $\mathrm{P}$ in the diets significantly improved the mean weight gain and specific growth rate in comparison with fish fed the control diet.

The two parameters increased progressively from the fish fed the control diet up to the fish fed diet containing $\mathrm{Ca} / \mathrm{P}$ ratio of $2: 1.5$, and thereafter declined consistently suggesting the $\mathrm{Ca} / \mathrm{P}$ ratio of $2: 1.5$ (1.33:1) as the optimum for the production of African catfish. This ratio is in very close relationship with the recommended ratio of 1:1 to $1: 1.7$ for fish (Ye et al. 2006). Paul et al. (2006) also reported that addition of Calcium and phosphorus in diets significantly increased the growth performance of Rohu, Labeo rohita fry in relation to fish fed the control diet.

The carcass quality of the fish fed experimental diets is presented in Table 3 .

Table 1. Gross composition of experimental diets $(\mathrm{g} / 100 \mathrm{~g})$

\begin{tabular}{lcccccc} 
& Table 1. Gross composition of experimental diets $(\mathrm{g} / 100 \mathrm{~g})$ \\
\hline & Diet 1 & Diet 2 & Diet 3 & Diet 4 & Diet 5 & Diet 6 \\
\hline Fish meal (72\% CP) & 25.0 & 25.0 & 25.0 & 25.0 & 25.0 & 25.0 \\
Soybean $(45 \% \mathrm{CP})$ & 24.0 & 24.0 & 24.0 & 24.0 & 24.0 & 24.0 \\
Groundnut cake (48\% CP) & 23.5 & 23.5 & 23.5 & 23.5 & 23.5 & 23.5 \\
Yellow maize & 16.0 & 16.0 & 16.0 & 16.0 & 16.0 & 16.0 \\
Vegetable oil & 5.00 & 5.00 & 5.00 & 5.00 & 5.00 & 5.00 \\
Vit-min premix & 5.00 & 5.00 & 5.00 & 5.00 & 5.00 & 5.00 \\
Methionine & 0.50 & 0.50 & 0.50 & 0.50 & 0.50 & 0.50 \\
Carboxylmethylcellulose & 1.00 & 1.00 & 1.00 & 1.00 & 1.00 & 1.00 \\
Ca(CaCO $\left.)_{3}\right)$ & 0.00 & 1.00 & 1.00 & 2.00 & 3.00 & 3.50 \\
P (KH2PO $\left.{ }_{4}\right)$ & 0.00 & 0.50 & 1.00 & 1.50 & 1.00 & 1.50 \\
\hline Proximate composition $(\%)$ & & & & & & \\
\hline Protein & 39.8 & 39.7 & 39.6 & 39.5 & 39.5 & 39.6 \\
Fat & 8.8 & 8.62 & 8.26 & 8.17 & 8.07 & 7.94 \\
Ash & 12.4 & 12.4 & 13.7 & 16 & 16.4 & 19.3 \\
Fibre & 3.4 & 3.15 & 3.15 & 3.17 & 3.18 & 3.18 \\
Moisture & 5.76 & 5.61 & 5.39 & 5.56 & 5.57 & 5.26 \\
Nitrogen free extract & 29.8 & 30.5 & 29.9 & 27.6 & 27.3 & 25.1 \\
\hline
\end{tabular}


Table 2. Growth and nutrient utilization of African catfish fed the experimental diets

\begin{tabular}{lllllll}
\hline & Diet 1 & Diet 2 & Diet 3 & Diet 4 & Diet 5 & Diet 6 \\
\hline Initial weight (g) & $7.70^{\mathrm{a}} \pm 0.06$ & $7.70^{\mathrm{a}} \pm 0.00$ & $7.70^{\mathrm{a}} \pm 0.00$ & $7.60^{\mathrm{a}} \pm 0.06$ & $7.67^{\mathrm{a}} \pm 0.03$ & $7.67^{\mathrm{a}} \pm 0.03$ \\
Final weight $(\mathrm{g})$ & $19.3^{\mathrm{a}} \pm 0.03$ & $25.4^{\mathrm{a}} \pm 0.01$ & $26.0^{\mathrm{a}} \pm 0.01$ & $26.6^{\mathrm{a}} \pm 0.08$ & $25.2^{2} \pm 0.01$ & $24.4^{\mathrm{a}} \pm 0.01$ \\
Mean weight gain (g) & $11.6^{\mathrm{a}} \pm 0.02$ & $17.7^{\mathrm{b}} \pm 0.05$ & $18.3^{\mathrm{b}} \pm 0.01$ & $19.0^{\mathrm{b}} \pm 0.05$ & $17.0^{ \pm} \pm 0.01$ & $16.5^{\mathrm{b}} \pm 0.01$ \\
SGR (\% day) & $1.31^{\mathrm{a}} \pm 0.01$ & $1.71^{\mathrm{b}} \pm 0.01$ & $1.74^{\mathrm{b}} \pm 0.01$ & $1.79^{\mathrm{b}} \pm 0.01$ & $1.70^{\mathrm{b}} \pm 0.01$ & $1.65^{\mathrm{b}} \pm 0.01$ \\
Feed conversion ratio & $2.59^{\mathrm{c}} \pm 0.35$ & $2.19^{\mathrm{ab}} \pm 0.35$ & $1.77^{\mathrm{a}} \pm 0.26$ & $1.45^{\mathrm{a}} \pm 0.09$ & $2.15^{\mathrm{a}} \pm 0.56$ & $2.17^{\mathrm{ab}} \pm 0.09$ \\
ADC (protein) & $50.0^{\mathrm{a}} \pm 0.21$ & $58.2^{\mathrm{b}} \pm 0.31$ & $60.0^{\mathrm{b}} \pm 0.11$ & $58.2^{\mathrm{b}} \pm 0.21$ & $59.9^{\mathrm{b}} \pm 0.21$ & $59.7^{\mathrm{b}} \pm 0.22$ \\
\hline
\end{tabular}

Means in the same row with similar superscripts are not different $(P>0.05)$

Table 3. Proximate composition of the fish fed experimental diets (\%)

\begin{tabular}{llccccc}
\hline Protein & $58.5^{\mathrm{a}} \pm 2.11$ & $60.8^{\mathrm{a}} \pm 1.46$ & $60.8^{\mathrm{a}} \pm 1.12$ & $57.5^{\mathrm{a}} \pm 1.47$ & $58.7^{\mathrm{a}} \pm 1.92$ & $56.4^{\mathrm{a}} \pm 1.68$ \\
Fat & $20.1^{\mathrm{b}} \pm 1.59$ & $17.8^{\mathrm{a}} 0.34$ & $17.8^{\mathrm{a}} \pm 0.59$ & $17.8^{\mathrm{a}} \pm 0.59$ & $17.9^{\mathrm{a}} \pm 0.66$ & $17.4^{\mathrm{a}} \pm 0.85$ \\
Ash & $10.9^{\mathrm{a}} \pm 0.59$ & $15.0^{\mathrm{b}} \pm 0.24$ & $14.7^{\mathrm{b}} \pm 0.07$ & $14.0^{\mathrm{b}} \pm 0.38$ & $13.9^{\mathrm{b}} \pm 2.08$ & $16.5^{\mathrm{b}} \pm 0.01$ \\
Moisture & $5.40^{\mathrm{b}} \pm 0.14$ & $3.14^{\mathrm{a}} \pm 0.34$ & $3.33^{\mathrm{a}} \pm 0.28$ & $3.53^{\mathrm{a}} \pm 0.68$ & $3.30^{\mathrm{a}} \pm 0.24$ & $3.63^{\mathrm{a}} \pm 0.09$ \\
\hline \multicolumn{7}{c}{}
\end{tabular}

Table 4. Mineral composition of the fish fed experimental diets (mg/g)

\begin{tabular}{lcccccc}
\multicolumn{7}{c}{ Table 4. Mineral composition of the fish fed experimental diets $(\mathrm{mg} / \mathrm{g})$} \\
\hline $\mathrm{Ca}(\mathrm{mg} / \mathrm{g})$ & Diet 1 & Diet 2 & Diet 3 & Diet 4 & Diet 5 & Diet 6 \\
$\mathrm{Mg}(\mathrm{mg} / \mathrm{g})$ & $23.8^{\mathrm{a}} \pm 0.01$ & $27.9^{\mathrm{b}} \pm 0.00$ & $32.4^{\mathrm{c}} \pm 0.00$ & $33.5^{\mathrm{d}} \pm 0.00$ & $35.2^{\mathrm{e}} \pm 0.00$ & $36.3^{\mathrm{f}} \pm 0.00$ \\
$\mathrm{P}(\mathrm{mg} / \mathrm{g})$ & $19.4^{\mathrm{a}} \pm 0.00$ & $20.3^{\mathrm{b}} \pm 0.01$ & $21.0^{\mathrm{c}} \pm 0.00$ & $21.5^{\mathrm{d}} \pm 0.01$ & $24.2^{\mathrm{e}} \pm 0.00$ & $24.8^{\mathrm{f}} \pm 0.01$ \\
$\mathrm{Zn}(\mathrm{ug} / \mathrm{g})$ & $19.4^{\mathrm{a}} \pm 0.02$ & $28.2^{\mathrm{b}} \pm 0.01$ & $31.5^{\mathrm{c}} \pm 0.02$ & $39.2^{\mathrm{d}} \pm 0.01$ & $39.4^{\mathrm{de}} \pm 0.00$ & $39.8^{\mathrm{e}} \pm 0.01$ \\
$\mathrm{Fe}(\mathrm{ug} / \mathrm{g})$ & $11.4^{\mathrm{a}} \pm 0.00$ & $7.23^{\mathrm{a}} \pm 0.00$ & $7.42^{\mathrm{a}} \pm 0.00$ & $8.14^{\mathrm{b}} \pm 0.00$ & $8.33^{\mathrm{b}} \pm 0.00$ & $8.43^{\mathrm{b}} \pm 0.00$ \\
$\mathrm{Mn}(\mathrm{ug} / \mathrm{g})$ & $2.34^{\mathrm{a}} \pm 0.00$ & $12.2^{\mathrm{b}} \pm .01$ & $12.4^{\mathrm{b}} \pm 0.00$ & $12.1^{\mathrm{b}} \pm 0.00$ & $12.2^{\mathrm{b}} \pm 0.00$ & $12.3^{\mathrm{b}} \pm 0.00$ \\
\multicolumn{7}{c}{ Means in the same row with similar superscripts are not different $(P>0.05)$}
\end{tabular}

Table 5. Haematological parameters of the fish fed experimental diets (mg/g)

\begin{tabular}{lcccccc}
\multicolumn{5}{c}{ Table 5. Haematological parameters of the fish fed experimental diets $(\mathrm{mg} / \mathrm{g})$} \\
\hline & Diet 1 & Diet 2 & Diet 3 & Diet 4 & Diet 5 & Diet 6 \\
\hline $\mathrm{PCV}(\%)$ & $29.3^{\mathrm{a}} \pm 0.88$ & $28.3^{\mathrm{a}} \pm 0.88$ & $28.7^{\mathrm{a}} \pm 0.87$ & $28.7^{\mathrm{a}} \pm 1.20$ & $28.3^{\mathrm{a}} \pm 1.67$ & $28.7^{\mathrm{a}} \pm 1.20$ \\
$\mathrm{Hb}(\%)$ & $9.73^{\mathrm{a}} \pm 0.31$ & $9.53^{\mathrm{a}} \pm 0.30$ & $9.53^{\mathrm{a}} \pm 0.31$ & $9.53^{\mathrm{a}} \pm 0.39$ & $9.13^{\mathrm{a}} \pm 0.56$ & $9.53^{\mathrm{a}} \pm 0.40$ \\
$\mathrm{RBC}\left(10^{6} \mathrm{~mm}^{3}\right)$ & $1.56^{\mathrm{a}} \pm 0.23$ & $1.44^{\mathrm{a}} \pm 0.21$ & $1.48^{\mathrm{a}} \pm 0.22$ & $1.51^{\mathrm{a}} \pm 0.11$ & $1.21^{\mathrm{a}} \pm 0.22$ & $1.47^{\mathrm{a}} \pm 0.21$ \\
$\mathrm{WBC}\left(10^{6} \mathrm{~mm}^{3}\right)$ & $1.13^{\mathrm{a}} \pm 0.11$ & $1.10^{\mathrm{a}} \pm 0.12$ & $1.14^{\mathrm{a}} \pm 0.13$ & $1.20^{\mathrm{a}} \pm 0.13$ & $0.98^{\mathrm{a}} \pm 0.14$ & $1.14^{\mathrm{a}} \pm 0.21$ \\
\hline \multicolumn{7}{c}{ Means in the same row with similar superscripts are not different $(P>0.05)$}
\end{tabular}

The table indicated that addition of $\mathrm{Ca}$ and $\mathrm{P}$ in the diets reduced the fat and moisture content of the fish, but increased the ash content to significant levels in comparison with fish in the control treatment. Paul et al. (2006) reported similar increment in the carcass ash of Rohu fed diets containing different $\mathrm{Ca} / \mathrm{P}$ ratios. The increment in ash content from the present study resulted in significant increase in the carcass minerals (Ca, Mg, P and Z) deposition in the fish ((Table 4). This supports the findings of (Hassan et al. 2013) that increasing $\mathrm{Ca} / \mathrm{P}$ ratio significantly increased the carcass ash of Nile tilapia because the salts enhanced mineral absorptions in the intestine. Similar observation has been reported for juvenile yellowtail, Seriola quinqueradiata (Sarker et al. 2012). Table 5 presents the haematological parameters of the fish which revealed that addition of $\mathrm{Ca}$ and $\mathrm{P}$ in the diets did not have any noticeable effect on the pack cell volume, haemoglobin, red blood cells and white blood cells, erythrocyte and leucocyte of the fish fed experimental diets. Hassan et al (2013) similarly reported that addition of different $\mathrm{Ca} / \mathrm{P}$ ratios in the diets did not significantly affect some blood parameters, alanine aminotransferase (ALT) and aspartate aminotransferase in the serum of Nile tilapia.
Conclusion: The $\mathrm{Ca} / \mathrm{P}$ ratio of $2: 1.5$ (1.33:1) was determined for Clarias gariepinus juvenile. Addition of calcium and phosphorus in the diets increased carcass ash and mineralization in Clarias gariepinus and this knowledge could be exploited in the production of low costs fish feed through reduction in the quantity and costs of minerals supplementation in the diets.

\section{REFERENCES}

Association of Official Analytical Chemists (AOAC). 1990. Official methods of analysis of the association of official analytical chemists, Vol. 1, 14th ed., 1102. Arlington, VA: Association of Official Analytical Chemists.

Duncan, DB (1955). Multiple range and multiple F tests. Biometrics 11:1-42.

Hassan, MS; Soltan, MA; Agouz, HM; Badr, AM (2013). Influences of calcium/phosphorus ratio on supplemental microbial phytase efficiency for Nile tilapia (Oreochromis niloticus). Egyptian Journal of Aquatic Research, 39, 205-213. 
Kumar, V; Sinha, AK; Makkar, HPS; De Boeck, G; Becker, K (2011). Phytate and Phytase in fish nutrition, animal physiology and animal nutrition. http://dx.doi.org 0396.2011.01169.s

10.1111.j-1439-

Nakamura, Y (1982). Effects of dietary phosphorus and calcium contents on the absorption of phosphorus in the digestive tract of carp. Japanese Journal of Scie. And Fisheries. 51: 605-608.

Nwanna, LC; Keuhlwein, H; Schwarz, FJ (2010). Phosphorus requirement of common carp (Cyprinus carpio L) based on growth and mineralization. Aquacult Research. 41: 401-410.

Nwanna, LC; Ogundowole, OE; Nwanna, EE (2014). Use of plantain (Musa paradisiaca) peels in low cost diets for enhancement of growth and carcass quality of African catfish.

J. Appl. Aquacult. 26 (1): 1-10.

Paul, BN; Sarkar, S; Giri, SS; Mohanty, SN; Mukhopadyhay; PK (2006). Dietary calcium and phosphorus requirements of Rohu Labeo rohita fry. Anim. Nutrition and Feed Technology, 6: 257-263.
Svobodova, Z; Vykusova, B; Modra, H; Jarkovsky, J; Smutna, M (2006). Haematological and biochemical profile of harvest-size carp during harvest and post-harvest storage. Aquacult. Research 37:959-965.

Sarkar, MSA, Satoh, S; Kamata, K; Haga, Y; Yamamoto, Y (2012). Supplementation effect(s) of organic acids and/or lipid plant protein-based diets on juvenile yellowtail,Seriola quinqueradiata, growth and, nitrogen and phosphorus excretion. Aquacult. Res. 43, 538545.

Ye, CX; Liu, YJ; Tian, LX; Mai, KS; Du, ZY (2006). Effect of dietarycalcium and phosphorus on growth, food efficiency, mineral content and body composition of juvenile grouper. Epinephelus coioides. Aquaculture, 255, 263-171. 